Article

\title{
One-Dimensional Coordination Polymers of Lanthanide Cations to Cucurbit[7]uril Built Using a Range of Tetrachloride Transition-Metal Dianion Structure Inducers
}

Li-Li Liang ${ }^{1}$, Yi Zhao ${ }^{2}$, Kai Chen ${ }^{1}$, Xin Xiao ${ }^{1}$, Jack K. Clegg ${ }^{3}$, Yun-Qian Zhang ${ }^{1}$, Zhu Tao ${ }^{1}$, Sai-Feng Xue ${ }^{1}$, Qian-Jiang Zhu ${ }^{1, *}$ and Gang Wei ${ }^{4, *}$

1 Key Laboratory of Macrocyclic and Supramolecular Chemistry of Guizhou Province, Guizhou University, Guiyang 550025, China; E-Mails: liangli2006768@126.com (L.-L.L.); kaichen85@gmail.com (K.C.); gyhxxiaoxin@163.com (X.X.); sci.yqzhang@gzu.edu.cn (Y.-Q.Z.); gzutao@263.net (Z.T.); sfxue@gzu.edu.cn (S.-F.X.)

2 College of Chemistry and Chemical Engineering, Anhui University of Technology, Maanshan 243002, China; E-Mail: zhaoyi0511@126.com

3 School of Chemistry and Molecular Biosciences, The University of Queensland, Brisbane St Lucia, QLD 4072, Australia; E-Mail: j.clegg@uq.edu.au

4 Commonwealth Scientific and Industrial Research Organisation, Materials Science and Engineering, P.O. Box 218, Lindfield, NSW 2070, Australia

* Authors to whom correspondence should be addressed; E-Mails: zqjgzu@126.com (Q.-J.Z.); gang.wei@csiro.au (G.W.); Tel./Fax: +86-851-3620-906 (Q.-J.Z.).

Received: 18 March 2013; in revised form: 30 April 2013 / Accepted: 3 May 2013 /

Published: 16 May 2013

Abstract: A number of linear coordination polymers have been assembled from lanthanide cations $\left(\mathrm{Ln}^{3+}\right)$ and cucurbit[7]uril $(\mathrm{Q}[7])$ in the presence of $\left[\mathrm{CuCl}_{4}\right]^{2-}$ or $\left[\mathrm{CoCl}_{4}\right]^{2-}$ anions acting as inorganic structure inducers in $\mathrm{HCl}$ solution. X-ray diffraction analysis has revealed that they form three groups of isomorphous structures. Generally, the complexes of Q[7] with light lanthanide cations (those with atomic number below that of neodymium $\left.\left(\mathrm{Nd}^{3+}\right)\right)$ are in one group. The other two groups, in which the lanthanide cation has atomic number greater than that of europium $\left(\mathrm{Eu}^{3+}\right)$, seem to follow no obvious rule. For example, the complexes of $\mathrm{Q}[7]$ with $\mathrm{Eu}^{3+}$ and $\mathrm{Gd}^{3+}$ cations are in the second group in the presence of $\left[\mathrm{CuCl}_{4}\right]^{2-}$ anions, while they are in the third group in the presence of $\left[\mathrm{CoCl}_{4}\right]^{2-}$ anions. However, whatever group a given complex belongs to, they all show a common honeycomb-patterned supramolecular assembly, in which $\left[\mathrm{CuCl}_{4}\right]^{2-}$ or $\left[\mathrm{CoCl}_{4}\right]^{2-}$ anions 
form a honeycomb structure. The $\mathrm{Ln}^{3+}$ cations then coordinate to neighboring Q[7] molecules to form 1D coordination polymers that are inserted into the channels of the honeycomb framework, such that each individual coordination polymer is surrounded by $\left[\mathrm{CuCl}_{4}\right]^{2-}$ or $\left[\mathrm{CoCl}_{4}\right]^{2-}$ anions.

Keywords: cucurbit[7]uril; lanthanide cation; inorganic inducers; 1D coordination polymers

\section{Introduction}

Coordination polymers are described as polymers whose repeat units are coordination complexes. Similar supramolecular architectures are also called metal-organic frameworks (MOFs), as well as coordination networks, with some inconsistency in the distinctions between the terms [1-6]. Coordination polymers span scientific fields such as organic and inorganic chemistry, biology, materials science, electrochemistry and pharmacology and have many potential applications [7]. This interdisciplinary nature has led to extensive study over the past few decades [8].

Cucurbit $[n]$ urils $(\mathrm{Q}[n] \mathrm{s})$ [9-14] consist of a rigid hydrophobic cavity of low polarity, accessible through two open polar portals rimmed with carbonyl groups, which can interact with various metal ions [15-26], or their complexes [27-40] or clusters [41-50], Consequently, cucurbit $[n]$ uril(Q $[n] \mathrm{s})$-based coordination chemistry is becoming an important area of study in cucurbit $[n]$ uril chemistry. In particular, $\mathrm{Q}[n] \mathrm{s}$ interact with metal ions and form various poly-dimensional coordination polymers [51-60]. For example, Kim et al. first demonstrated one-dimensional coordination polymers alternating between alkali-metal ions $\left(\mathrm{K}^{+}\right.$or $\mathrm{Rb}^{+}$cation) and $\mathrm{Q}[6]$ molecules [51,52]. Chen et al. also demonstrated one-dimensional supramolecular chains constructed from the direct coordination of Q[6]s with $\mathrm{Na}^{+}$ cations [53]. In recent years, there has been a trend towards introducing an organic or inorganic species into the metal-Q $[n]$ systems as a "structure inducer" or trigger, since the properties, structural novelties, and functionalities of the resulting coordination polymers have often exceeded those observed in the absence of such agents. Following on from Fedin's work [30,32], Thuéry focused on the $\mathrm{Q}[n]$ complexation of lanthanides and actinides and demonstrated the formation of a series of lanthanide-Q $[n]$ and uranyl-Q $[n]$ supramolecular assemblies in the presence of added organic ligands [34-37]. Since a novel potassium-Q[5] supramolecular network was first prepared in the presence of $p$-hydroxybenzoic acid [60], coordination of metal ions to $\mathrm{Q}[n] \mathrm{s}$ in the presence of various organic molecules has been extensively studied in our laboratory, and a strategy for inorganic or organic molecule-induced coordination polymers of metal ions to $\mathrm{Q}[n] \mathrm{s}$ has gradually been established. A series of $\mathrm{Q}[n]$-based poly-dimensional polymers [54,58-63] have been obtained by using this strategy.

In the present work, in order to better understand how inorganic inducers influence the coordination of metal ions to $\mathrm{Q}[n]$, leading to the construction of such coordination polymers, we further investigate the coordination of lanthanides to $\mathrm{Q}[7]$ in the presence of $\left[\mathrm{CuCl}_{4}\right]^{2-}$ and $\left[\mathrm{CoCl}_{4}\right]^{2-}$ anions. X-ray diffraction analysis has revealed that coordination of lanthanide ions to $\mathrm{Q}[7]$ leads to the formation of linear one-dimensional coordination polymers, while the presence of $\left[\mathrm{CuCl}_{4}\right]^{2-}$ or $\left[\mathrm{CoCl}_{4}\right]^{2-}$ anions gives rise to the so called "honeycomb effect", forming honeycomb-like hollows in which these linear one-dimensional $\mathrm{Ln}^{3+}-\mathrm{Q}[7]$ polymers can reside. 


\section{Experimental Section}

Synthesis: Chemicals, such as lanthanide nitrates and hydrochloric acid, were of reagent grade and were used without further purification. Q[7] was prepared as reported elsewhere [10,11]. Elemental analyses were carried out on a EURO EA-3000 elemental analyzer. Aqueous $\mathrm{HCl}\left(6.0 \mathrm{~mol} \mathrm{~L}^{-1}\right)$ was used to prepare crystals of Q[7]- $\mathrm{Ln}$ (III) in the presence of $\mathrm{CuCl}_{2} \cdot 2 \mathrm{H}_{2} \mathrm{O}$ or $\mathrm{CoCl}_{2} \cdot 6 \mathrm{H}_{2} \mathrm{O}$. A similar process was used to prepare crystals of related compounds: $\mathrm{Ln}\left(\mathrm{NO}_{3}\right)_{3} \cdot x \mathrm{H}_{2} \mathrm{O}(0.136 \mathrm{mmol})$ and $\mathrm{CuCl}_{2} \cdot 2 \mathrm{H}_{2} \mathrm{O}$ (15.24 mg, $0.089 \mathrm{mmol}$ ) were dissolved in $2.0 \mathrm{~mL} 6.0 \mathrm{~mol} \mathrm{~L}{ }^{-1} \mathrm{HCl}$ (solution A), Q[7] (20 mg, $0.017 \mathrm{mmol}$ ) was dissolved in $2.0 \mathrm{~mL} 6.0 \mathrm{~mol} \mathrm{~L}^{-1} \mathrm{HCl}$ (solution $\mathrm{B}$ ), and was then added in the solution A with stirring for the $\mathrm{Ln}^{3+}-\mathrm{Q}[7]-\left[\mathrm{CuCl}_{4}\right]^{2-}$ systems. $\mathrm{Ln}\left(\mathrm{NO}_{3}\right)_{3} \cdot x \mathrm{H}_{2} \mathrm{O}(0.119 \mathrm{mmol})$ and $\mathrm{CoCl}_{2} \cdot 6 \mathrm{H}_{2} \mathrm{O}(21.28 \mathrm{mg}, 0.089 \mathrm{mmol})$ were dissolved in $2.0 \mathrm{~mL} 6.0 \mathrm{~mol} \mathrm{~L}{ }^{-1} \mathrm{HCl}$ (solution C), to solution $\mathrm{C}(2.0 \mathrm{~mL})$ was added in solution $\mathrm{B}(2.0 \mathrm{~mL})$ with stirring for the $\mathrm{Ln}^{3+}-\mathrm{Q}[6]-\left[\mathrm{CoCl}_{4}\right]^{2-}$ systems. X-ray quality crystals were obtained from the solution over a period of 1-7 days. The color of crystals was dependent on the lanthanide ions. Summarizing the preparations, $\left\{\mathrm{La}_{2}\left(\mathrm{H}_{2} \mathrm{O}\right)_{12} \mathrm{Q}[7]\right\} 2\left[\mathrm{CuCl}_{4}\right] \cdot 2 \mathrm{Cl} \cdot 28 \mathrm{H}_{2} \mathrm{O}$ (1) was obtained from $\mathrm{La}\left(\mathrm{NO}_{3}\right)_{3} \cdot 6 \mathrm{H}_{2} \mathrm{O} \quad(51.62 \mathrm{mg})$; $\left\{\mathrm{Nd}_{2}\left(\mathrm{H}_{2} \mathrm{O}\right)_{12} \mathrm{Q}[7]\right\} 2\left[\mathrm{CuCl}_{4}\right] \cdot 2 \mathrm{Cl} \cdot 28 \mathrm{H}_{2} \mathrm{O}$ (2) was obtained from $\mathrm{Nd}\left(\mathrm{NO}_{3}\right)_{3} \cdot \mathrm{H}_{2} \mathrm{O} \quad(39.37 \mathrm{mg})$; $\left\{\mathrm{La}_{2}\left(\mathrm{H}_{2} \mathrm{O}\right)_{12} \mathrm{Q}[7]\right\}\left[\mathrm{CoCl}_{4}\right] \cdot 4 \mathrm{Cl} \cdot 57 \mathrm{H}_{2} \mathrm{O}$ (3) was obtained from $\mathrm{La}\left(\mathrm{NO}_{3}\right)_{3} \cdot 6 \mathrm{H}_{2} \mathrm{O} \quad(51.62 \mathrm{mg})$; $\left\{\mathrm{Ce}_{2}\left(\mathrm{H}_{2} \mathrm{O}\right)_{12} \mathrm{Q}[7]\right\}\left[\mathrm{CoCl}_{4}\right] \cdot 4 \mathrm{Cl} \cdot 26 \mathrm{H}_{2} \mathrm{O}$ (4) was obtained from $\mathrm{Ce}\left(\mathrm{NO}_{3}\right)_{3} \cdot 6 \mathrm{H}_{2} \mathrm{O} \quad(51.76 \mathrm{mg})$; $\left\{\mathrm{Eu}_{2}\left(\mathrm{H}_{2} \mathrm{O}\right)_{10} \mathrm{Q}[7]\right\}\left[\mathrm{CuCl}_{4}\right] \cdot 4 \mathrm{Cl} \cdot 39 \mathrm{H}_{2} \mathrm{O}$ (5) was obtained from $\mathrm{Eu}\left(\mathrm{NO}_{3}\right)_{3} \cdot 6 \mathrm{H}_{2} \mathrm{O} \quad(53.17 \mathrm{mg})$; $\left\{\mathrm{Gd}_{2}\left(\mathrm{H}_{2} \mathrm{O}\right)_{10} \mathrm{Q}[7]\right\}\left[\mathrm{CuCl}_{4}\right] \cdot 4 \mathrm{Cl} \cdot 43 \mathrm{H}_{2} \mathrm{O}$ (6) was obtained from $\mathrm{Gd}\left(\mathrm{NO}_{3}\right)_{3} \cdot 6 \mathrm{H}_{2} \mathrm{O} \quad(53.81 \mathrm{mg})$; $\left\{\mathrm{Dy}_{2}\left(\mathrm{H}_{2} \mathrm{O}\right)_{10} \mathrm{Q}[7]\right\}\left[\mathrm{CoCl}_{4}\right] \cdot 4 \mathrm{Cl} \cdot 39 \mathrm{H}_{2} \mathrm{O}$ (7) was obtained from $\mathrm{Dy}\left(\mathrm{NO}_{3}\right)_{3} \cdot 6 \mathrm{H}_{2} \mathrm{O} \quad(57.66 \mathrm{mg})$; $\left\{\mathrm{Er}_{2}\left(\mathrm{H}_{2} \mathrm{O}\right)_{10} \mathrm{Q}[7]\right\}\left[\mathrm{CoCl}_{4}\right] \cdot 4 \mathrm{Cl} \cdot 47 \mathrm{H}_{2} \mathrm{O} \quad$ (8) was obtained from $\operatorname{Er}\left(\mathrm{NO}_{3}\right)_{3} \cdot 5 \mathrm{H}_{2} \mathrm{O} \quad(52.86 \mathrm{mg})$; $\left\{\mathrm{Eu}_{2}\left(\mathrm{H}_{2} \mathrm{O}\right)_{10} \mathrm{Q}[7]\right\}\left[\mathrm{CoCl}_{4}\right] \cdot 4 \mathrm{Cl} \cdot 34 \mathrm{H}_{2} \mathrm{O}$ (9) was obtained from $\mathrm{Eu}\left(\mathrm{NO}_{3}\right)_{3} \cdot 6 \mathrm{H}_{2} \mathrm{O} \quad(53.17 \mathrm{mg})$; $\left\{\mathrm{Gd}_{2}\left(\mathrm{H}_{2} \mathrm{O}\right)_{10} \mathrm{Q}[7]\right\}\left[\mathrm{CoCl}_{4}\right] \cdot 4 \mathrm{Cl} \cdot 34 \mathrm{H}_{2} \mathrm{O} \quad$ (10) was obtained from $\mathrm{Gd}\left(\mathrm{NO}_{3}\right)_{3} \cdot 6 \mathrm{H}_{2} \mathrm{O} \quad(53.81 \mathrm{mg})$; $\left\{\mathrm{Dy}_{2}\left(\mathrm{H}_{2} \mathrm{O}\right)_{10} \mathrm{Q}[7]\right\}\left[\mathrm{CuCl}_{4}\right] \cdot 4 \mathrm{Cl} \cdot 46 \mathrm{H}_{2} \mathrm{O}$ (11) was obtained from $\mathrm{Dy}\left(\mathrm{NO}_{3}\right)_{3} \cdot 6 \mathrm{H}_{2} \mathrm{O} \quad(57.66 \mathrm{mg})$; $\left\{\mathrm{Ho}_{2}\left(\mathrm{H}_{2} \mathrm{O}\right)_{10} \mathrm{Q}[7]\right\}\left[\mathrm{CoCl}_{4}\right] \cdot 4 \mathrm{Cl} \cdot 55 \mathrm{H}_{2} \mathrm{O}(\mathbf{1 2})$ was obtained from $\mathrm{Ho}\left(\mathrm{NO}_{3}\right)_{3} \cdot 5 \mathrm{H}_{2} \mathrm{O}(52.58 \mathrm{mg})$; Elemental analysis results for the eight compounds are given in Table $\mathrm{S} 1$.

X-ray crystallography: A suitable single crystal $\left(\sim 0.2 \times 0.2 \times 0.1 \mathrm{~mm}^{3}\right)$ was taken up in paraffin oil and mounted on a Bruker SMART Apex II CCD diffractometer equipped with a graphite-monochromated Mo- $K_{\alpha}\left(\lambda=0.71073 \AA, \mu=0.828 \mathrm{~mm}^{-1}\right)$ radiation source operating in the $\omega$-scan mode and a nitrogen cold stream $\left(-50{ }^{\circ} \mathrm{C}\right)$. Data were corrected for Lorentz and polarization effects (SAINT), and semi-empirical absorption corrections based on equivalent reflections were also applied (SADABS). The structure was elucidated by direct methods and refined by the full-matrix least-squares method on $F^{2}$ with the SHELXS-97 and SHELXL-97 program packages, respectively [64,65]. All non-hydrogen atoms were refined anisotropically. Carbon-bound hydrogen atoms were introduced at calculated positions, and were treated as riding atoms with an isotropic displacement parameter equal to 1.2 times that of the parent atom. Most of the water molecules in the compounds were omitted using the SQUEEZE option of the PLATON program. Analytical expressions for neutral-atom scattering factors were employed, and anomalous dispersion corrections were incorporated. Details of the crystal parameters, data collection conditions, and refinement parameters for the twelve compounds are summarized in Table S2. In addition, the crystallographic 
data for the reported structures have been deposited at the Cambridge Crystallographic Data Centre as supplementary publication nos. CCDC-919403 (1), 919404 (2), 919405 (3), 919406 (4), 919407 (5), 919408 (6), 919411 (7), 919412 (8), 919409 (9), 919410 (10), 919413 (11), 919414 (12). These data can be obtained free of charge via CCDC CIF Depository Request [66], or by emailing data_request@ccdc.cam.ac.uk, or by contacting The Cambridge Crystallographic Data Centre, 12, Union Road, Cambridge CB2 1EZ, UK; fax: +44 1223336033.

\section{Results and Discussion}

In previous studies, there have been numerous attempts to grow single crystals of complexes in which lanthanide cations are coordinated to Q[7] in various acidic media, but all have proved unsuccessful. However, it was discovered that when lanthanide cations are introduced into a $\left[\mathrm{CdCl}_{4}\right]^{2-}-\mathrm{Q}[7]$ solution, $\mathrm{Ln}^{3+}-\mathrm{Q}$ [7] linear coordination polymers are readily produced, and the cadmium cation in the form of the tetrachloride, i.e., $\left[\mathrm{CdCl}_{4}\right]^{2-}$, can be arranged into honeycomb-like hollows. These hollows can then accommodate the one-dimensional $\mathrm{Ln}^{3+}-\mathrm{Q}[7]$ coordination polymers through ion-dipole and $\mathrm{C}-\mathrm{H} \cdots \mathrm{Cl}$ interactions coupled with metal coordination [61]. Subsequent research has revealed that several transition metal ions, such as $\mathrm{Zn}^{2+}, \mathrm{Cu}^{2+}$, and $\mathrm{Co}^{2+}$ etc., in the form of the tetrachloride anions, $\left[\mathrm{MCl}_{4}\right]^{2-}$, can play a similar role in triggering the formation of the one-dimensional $\mathrm{Ln}^{3+}-\mathrm{Q}[n]$ coordination polymers [62,63]. In the present work, we demonstrate the synthesis of a series of supramolecular assemblies of lanthanide cations and Q[7] molecules in the presence of $\left[\mathrm{CuCl}_{4}\right]^{2-}$ or $\left[\mathrm{CoCl}_{4}\right]^{2-}$ anions. Considering the similar chemical properties of the lanthanides, it is likely that the interaction of the various lanthanide cations with Q[7] molecules will give rise to similar coordination features and supramolecular assemblies. Indeed, the solid-state structures, as determined by X-ray crystallography, of the obtained complexes formed three isomorphous groups. Complexes of Q[7] with light lanthanide cations (those with atomic number less than that of neodymium $\left(\mathrm{Nd}^{3+}\right)$ ) are in the same group. There are two other groups for lanthanide cations with atomic numbers greater than europium $\left(\mathrm{Eu}^{3+}\right)$, but these seem to follow no obvious rule. For example, the complexes of Q[7] with $\mathrm{Eu}^{3+}$ and $\mathrm{Gd}^{3+}$ cations are in the second group in the presence of $\left[\mathrm{CuCl}_{4}\right]^{2-}$ anions, while they are in the third group in the presence of $\left[\mathrm{CoCl}_{4}\right]^{2-}$ anions. However, whichever complex belongs to which group, they all show a common supramolecular assembly, in which $\left[\mathrm{CuCl}_{4}\right]^{2-}$ or $\left[\mathrm{CoCl}_{4}\right]^{2-}$ anions form a honeycomb structure, and the $\mathrm{Ln}^{3+}$ cations coordinate to neighboring Q[7] molecules to form a 1D coordination polymer that is inserted into the channels of the honeycomb framework, so that each individual coordination polymer is surrounded by $\left[\mathrm{CuCl}_{4}\right]^{2-}$ or $\left[\mathrm{CoCl}_{4}\right]^{2-}$ anions.

An overall view of the coordination features and the supramolecular assembly of compound $\mathbf{1}$, as a representative example, is given in (Figure 1a). The $\left[\mathrm{CuCl}_{4}\right]^{2-}$ anions form a honeycomb structure (Figure $1 b$ ). The $\mathrm{La}^{3+}$ cations coordinate to neighboring Q[7] molecules and form the 1D coordination polymers inserted into the channels in the honeycomb. As a result, each individual tubular coordination polymer is surrounded by $\left[\mathrm{CuCl}_{4}\right]^{2-}$ anions (Figure 1c). Close inspection reveals that the neighboring Q[7] molecules in the coordination polymer are linked by two $\mathrm{La}^{3+}$ cations (2La1). Each La1 cation coordinates to nine oxygen atoms, namely three carbonyl oxygen atoms from two neighboring Q[7] molecules (O10, O11, and O14), and six water molecules (O3W, O4W, O5W, O8W, 
O10W and $\mathrm{O} 12 \mathrm{~W})$. The bond lengths of $\mathrm{La}-\mathrm{O}_{\text {carbonyl }}$ are in the range 2.514-2.557 $\AA$, and the bond lengths of $\mathrm{La}-\mathrm{O}_{\text {water }}$ are in the range 2.514-2.600 $\AA$ (see Figure 1d).

Figure 1. X-ray crystal structure of compound 1: (a) an overall view of the coordination features and supramolecular assembly; (b) the honeycomb-like framework composed of $\left[\mathrm{CuCl}_{4}\right]^{2-}$ anions; (c) a $1 \mathrm{D}$ coordination polymer of $\mathrm{La}^{3+}$ cations and Q[7] molecules surrounded by the $\left[\mathrm{CuCl}_{4}\right]^{2-}$ anions; (d) coordination of the $\mathrm{La}^{3+}$ cations by the portal carbonyl oxygens of the Q[7] molecules; (e) interaction of the $\left[\mathrm{CuCl}_{4}\right]^{2-}$ anions with the Q[7] molecules.
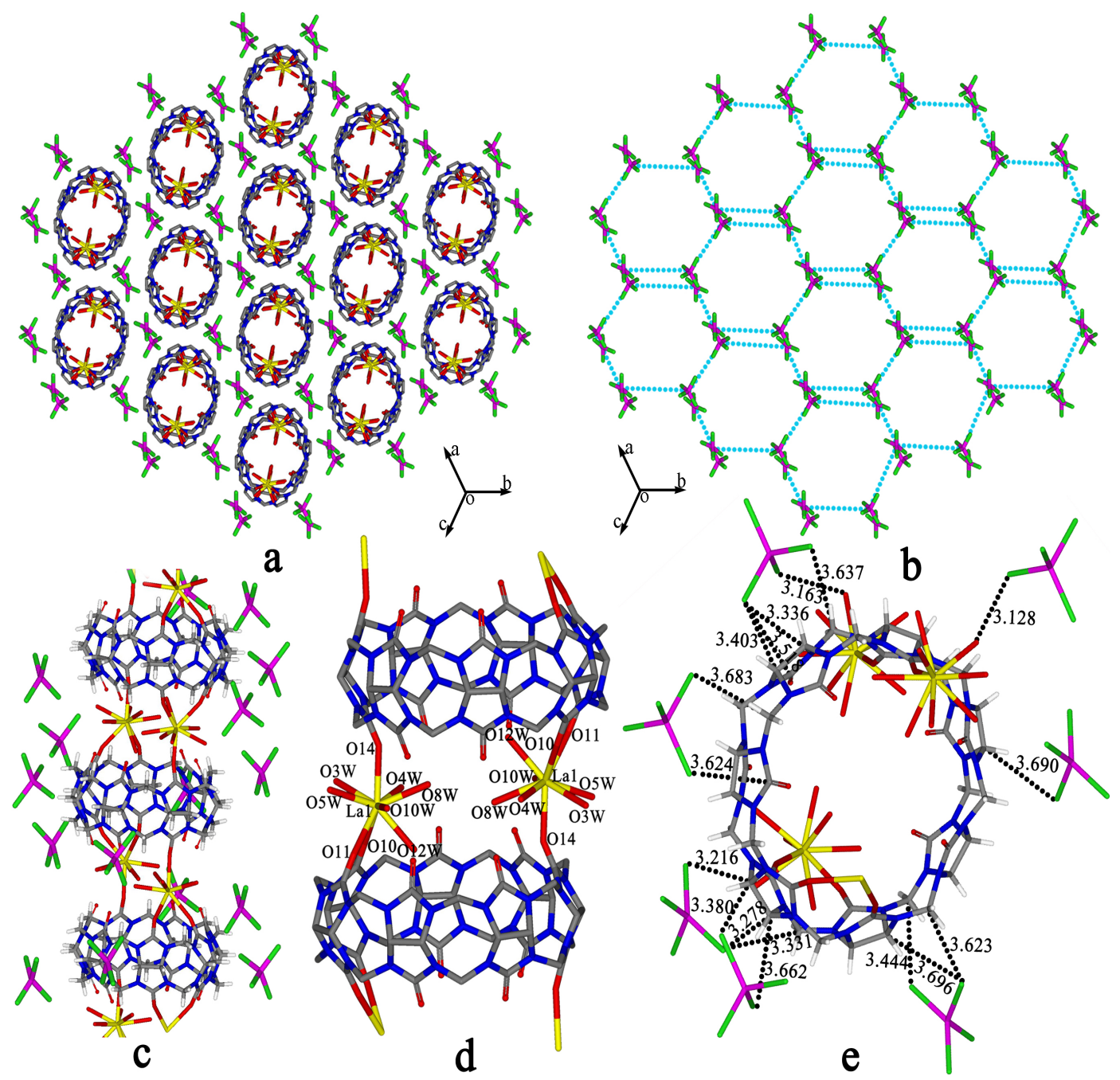

Most lanthanide cations can coordinate to the portal carbonyl oxygens of $\mathrm{Q}[n=6,7,8]$ molecules to form zigzag or tubular one-dimensional coordination polymers in the presence of $\left[\mathrm{MCl}_{4}\right]^{2-}$ anions ( $\mathrm{M}=\mathrm{Cd}, \mathrm{Zn}, \mathrm{Cu} \mathrm{Co}, \mathrm{Ni}$ and so on) [61-63], suggesting that these anions play the role of a structural inducer. The question then arises as to how the $\left[\mathrm{MCl}_{4}\right]^{2-}$ anions induce this coordination process. Kögerler et al. demonstrated a novel crystal structure, consisting of a hybrid complex based on Q[6], in which the driving forces for the interaction between Q[6 or 8] and the polyoxometallate were the electron-deficient carbon sites of the carbonyl dipole of $\mathrm{Q}[6$ or 8$]$ and the $\mathrm{V}=\mathrm{O}$ bonds of the polyoxometallate, as well as hydrogen bonding between the methine groups on an adjacent glycoluril unit and the oxygen of the polyoxometallate [67]. Based on this suggestion, it is reasonable to assume 
that the formation of the $\left[\mathrm{MCl}_{4}\right]^{2-}$ honeycomb is a consequence of ion-dipole interactions between the portal carbonyl carbon atoms and the chlorine atoms of the anions, as well as hydrogen bonding between the chlorine atoms of the anions and the methine groups on the surface of the $\mathrm{Q}[n]$ molecules. Moreover, the formation of the $\left[\mathrm{MCl}_{4}\right]^{2-}$ honeycomb is conducive to the coordination of lanthanide cations to $\mathrm{Q}[n]$ molecules. In the case of $\mathrm{La}-\mathrm{Q}[7]-\left[\mathrm{CuCl}_{4}\right]^{2-}$, each coordinated $\mathrm{Q}[7]$ molecule in the coordination polymer is surrounded by seven $\left[\mathrm{CuCl}_{4}\right]^{2-}$ anions (see Figure 1e). These interactions can include the ion-dipole interaction $\mathrm{O}=\mathrm{C}^{\delta+} \ldots \mathrm{Cl}^{-}-\mathrm{CuCl}_{3}{ }^{-}$where the interaction distances (black dashed lines) are in the range 3.469-3.624 $\AA$, the hydrogen bonding of $\mathrm{C}_{\text {methylene }}{ }^{\cdots} \mathrm{Cl}^{-}-\mathrm{CuCl}_{3}{ }^{-}$in the range 3.332-3.690 $\AA$ and the hydrogen bonding of $\mathrm{O}_{\text {water }} \cdots \mathrm{Cl}^{-}-\mathrm{CuCl}_{3}{ }^{-}$in the range 3.128-3.216 $\AA$ (dashed lines).

Compounds 2, 3, 4 have similar coordination and supramolecular assemblies and form the first isomorphous group with in which compound 2 was prepared in the presence of $\left[\mathrm{CuCl}_{4}\right]^{2-}$ anions, while compounds 3 and 4 were prepared in the presence of $\left[\mathrm{CoCl}_{4}\right]^{2-}$ anions (see Figures S1-S4). Generally, the tetrachloride transition-metal dianions form a tetrahedral pattern, such as $\left[\mathrm{CdCl}_{4}\right]^{2-}$ and $\left[\mathrm{ZnCl}_{4}\right]^{2-}$, where the bond angles of $\angle \mathrm{Cl}-\mathrm{M}_{\text {transition-metal }}-\mathrm{Cl}$ are close to $109^{\circ} 28^{\prime}$, generally in the range $105^{\circ}-112^{\circ}[61,62]$. In the present case, however, the bond angles $\angle \mathrm{Cl}-\mathrm{Cu}-\mathrm{Cl}$ are in the range $101^{\circ}-122^{\circ}$, so the $\left[\mathrm{CuCl}_{4}\right]^{2-}$ anions form a distorted tetrahedron. Similar results can be observed in the crystal structures of compounds with $\left[\mathrm{CuCl}_{4}\right]^{2-}$ anions, such as compounds $\mathbf{2}, \mathbf{5}, \mathbf{6}$ and $\mathbf{1 1}$, where the bond angles $\angle \mathrm{Cl}-\mathrm{Cu}-\mathrm{Cl}$ are in the range $101^{\circ}-121^{\circ}$. The bond angles $\angle \mathrm{Cl}-\mathrm{Co}-\mathrm{Cl}$ in the $\left[\mathrm{CoCl}_{4}\right]^{2-}$ anions are similar to those of $\left[\mathrm{CdCl}_{4}\right]^{2-}$ and $\left[\mathrm{ZnCl}_{4}\right]^{2-}$ and are in the range $106^{\circ}-112^{\circ}$ for compounds with the $\left[\mathrm{CoCl}_{4}\right]^{2-}$ anions, such as compounds 3, 4, 7, 8, 9, 10 and 12.

The $\mathrm{Ln}^{3+}-\mathrm{Q}[7]-\left[\mathrm{CuCl}_{4}\right]^{2-}$ or $\mathrm{Ln}^{3+}-\mathrm{Q}[7]-\left[\mathrm{CoCl}_{4}\right]^{2-}$ systems, with light lanthanides, generally give compounds isomorphous with those in the first group, while complexes containing heavier lanthanides can give complexes in the second or third groups. Although they belong to different isomorphous groups, the coordination of the lanthanide cation to the Q[7] molecules and the corresponding supramolecular assemblies are similar to those of the compounds in the first group. Firstly, the $\left[\mathrm{CuCl}_{4}\right]^{2-}$ or $\left[\mathrm{CoCl}_{4}\right]^{2-}$ anions form a "honeycomb effect" and are arranged into honeycomb structures (see Figure 2a,b and Figures S5-S12). Secondly, two $\mathrm{Ln}^{3+}$ cations are coordinated to neighboring Q[7] molecules to form tubular coordination polymers (see Figure 2c,d and Figures S5-S12). Finally, the tubular coordination polymers are inserted into the channels in the $\left[\mathrm{CuCl}_{4}\right]^{2-}$ - or $\left[\mathrm{CoCl}_{4}\right]^{2-}$-honeycomb framework, so that each individual tubular coordination polymer is surrounded by $\left[\mathrm{CuCl}_{4}\right]^{2-}$ or $\left[\mathrm{CoCl}_{4}\right]^{2-}$ anions. Eu ${ }^{3+}$ cations connect two neighboring Q[7] molecules resulting in the formation of tubular $\mathrm{Eu}^{3+}-\mathrm{Q}$ [7] polymers. Each $\mathrm{Eu}^{3+}$ cation is coordinated to eight oxygen atoms, three carbonyl oxygens belonging to two neighboring Q[7] molecules and five water molecules. Each Q[7] molecule is surrounded by four $\left[\mathrm{CuCl}_{4}\right]^{2-}$ or $\left[\mathrm{CoCl}_{4}\right]^{2-}$ anions through a combination of electrostatic interaction between $\mathrm{Eu}^{3+}$ cations and $\left[\mathrm{CuCl}_{4}\right]^{2-}$ or $\left[\mathrm{CoCl}_{4}\right]^{2-}$ anions, hydrogen bonding and ion-dipole interactions (see Figure 2c,f and Figures S5-S12). There exist two very similar tubular coordination polymers constructed from $\mathrm{Eu}^{3+}$ cations and $\mathrm{Q}[7]$ molecules. For example, a pair $\mathrm{Eu}^{3+}$ cations connects two neighboring $\mathrm{Q}[7]$ molecules, resulting in the formation of tubular $\mathrm{Eu}^{3+}-\mathrm{Q}$ [7] polymers. Close inspection reveals that the two $\mathrm{Eu}^{3+}$ cations in the pair are different in the two systems; they are the same in the $\mathrm{Eu}^{3+}-\mathrm{Q}[7]-\left[\mathrm{CuCl}_{4}\right]^{2-}$ system (the second isomorphous group) but different in the $\mathrm{Eu}^{3+}-\mathrm{Q}[7]-\left[\mathrm{CoCl}_{4}\right]^{2-}$ system (the second isomorphous group). However, the neighboring pair are 
different in the $\mathrm{Eu}^{3+}-\mathrm{Q}[7]-\left[\mathrm{CuCl}_{4}\right]^{2-}$ and the same in the $\mathrm{Eu}^{3+}-\mathrm{Q}[7]-\left[\mathrm{CoCl}_{4}\right]^{2-}$ system. Thus, the distances between the two $\mathrm{Eu}^{3+}$ cationsin the pair are different, as shown in Figure $2 \mathrm{c}, \mathrm{d}$.

Figure 2. X-ray crystal structure of compounds with light lanthanides: (a) and (b) an overall view of the coordination features and supramolecular assembly; (c) and (d) 1D coordination polymer ofEu ${ }^{3+}$ cations and Q[7] molecules surrounded by the $\left[\mathrm{CuCl}_{4}\right]^{2-}$ and $\left[\mathrm{CoCl}_{4}\right]^{2-}$ anions; (e) and (f) interaction of the $\left[\mathrm{CuCl}_{4}\right]^{2-}$ anions with the Q[7] molecules for compounds $\mathbf{5}$ and $\mathbf{9}$, respectively.

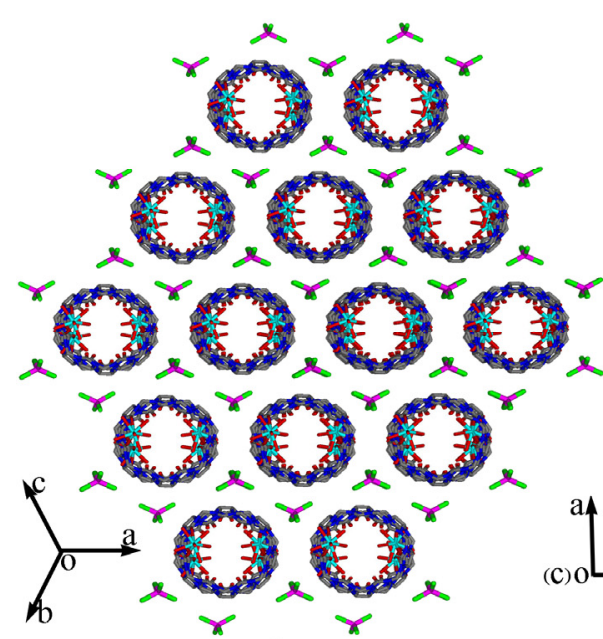

a

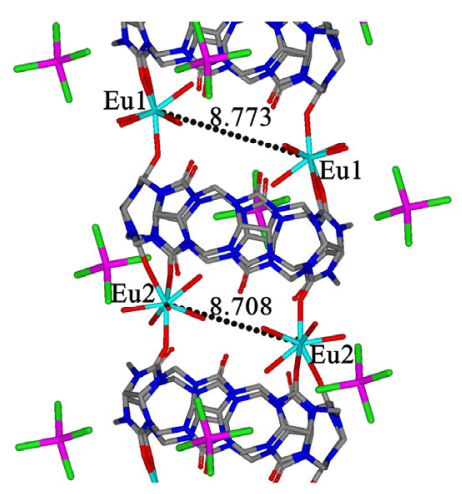

C

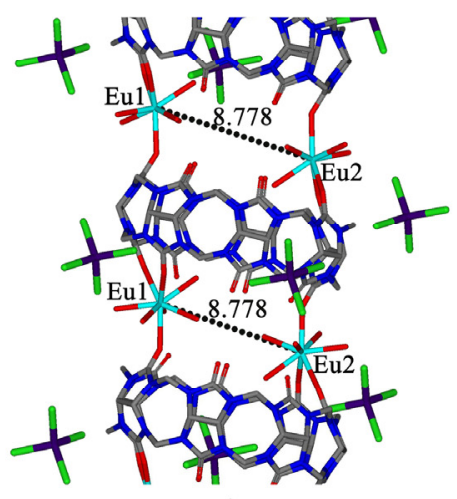

d

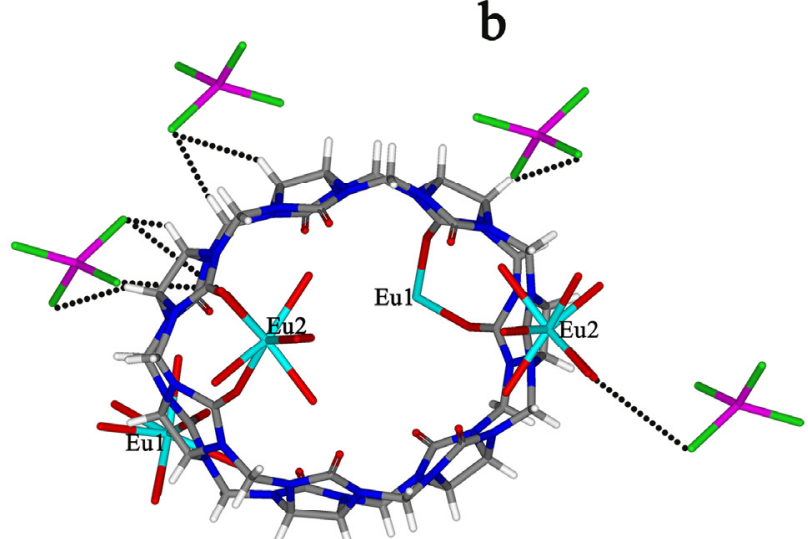

e

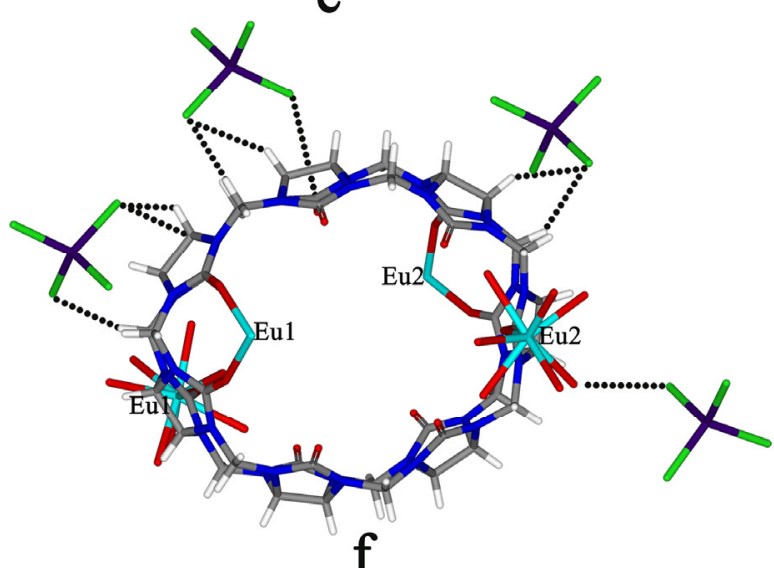

Figure 3a,b shows the coordination complexes for the two $\mathrm{Eu}^{3+}-\mathrm{Q}[7]$ compounds 5 and 9 obtained in the presence of the $\left[\mathrm{CuCl}_{4}\right]^{2-}$ and $\left[\mathrm{CoCl}_{4}\right]^{2-}$ anions, respectively. They belong to the second and 
third isomorphous groups, respectively. The angles of two planes of three of the four $\mathrm{Eu}^{3+}$ cations at the two portals of the Q[7] molecule are different, but the differences are not significant, both being close to $20^{\circ}\left(22.57^{\circ}\right.$ and $22.01^{\circ}$, respectively). These structural features can be observed in the other $\mathrm{Ln}^{3+}-\mathrm{Q}[7]-\left[\mathrm{CuCl}_{4}\right]^{2-}$ or $\mathrm{Ln}^{3+}-\mathrm{Q}[7]-\left[\mathrm{CoCl}_{4}\right]^{2-}$ systems, in which the $\mathrm{Ln}^{3+}$ are those with an atomic number greater than that of europium $\left(\mathrm{Eu}^{3+}\right)$ but smaller than erbium $\left(\mathrm{Er}^{3+}\right)$, which are compounds 5, 6, 9, 10 and 12 (referring to Figures S5-S12). Figure 3c gives the coordination complex in compound 1 belonging to the first isomorphous group. The angle is significantly different to the values in the second and third groups, being only $1.52^{\circ}$. Note that the torsion in complexes of other compounds in the first isomorphous group is similar to this value, close to zero, such as the complexes in compounds 2-4 (see Figures S1-S4). Thus, the differences in the three isomorphous groups basically depend on the coordination environment of the $\mathrm{Ln}^{3+}$ cations to $\mathrm{Q}[7]$ molecules. The tubular coordination polymers containing $\mathrm{Tm}, \mathrm{Yb}$ or $\mathrm{Lu}$ cations have not been synthesized since the slightly shorter ionic radii of these lanthanides make it difficult to coordinate to the cucurbit[ $n]$ urils. A similar situation has been observed in the $\mathrm{Ln}^{3+}-\mathrm{Q}[7]-\left[\mathrm{CdCl}_{4}\right]^{2-}[61], \mathrm{Ln}^{3+}-\mathrm{Q}[6]-\left[\mathrm{CdCl}_{4}\right]^{2-}$ and $\mathrm{Ln}^{3+}-\mathrm{Q}[6]-\left[\mathrm{ZnCl}_{4}\right]^{2-}$ systems.

Figure 3. X-ray crystal structure of compounds 5 and 9: (a) and (b) torsions of the four $\mathrm{Eu}^{3+}$ cations at the two portals of a Q[7] molecule in compounds $\mathbf{5}$ and 9, respectively; (c) torsion of the four $\mathrm{La}^{3+}$ cations at the two portals of a Q[7] molecule in compound $\mathbf{1}$ for comparison.
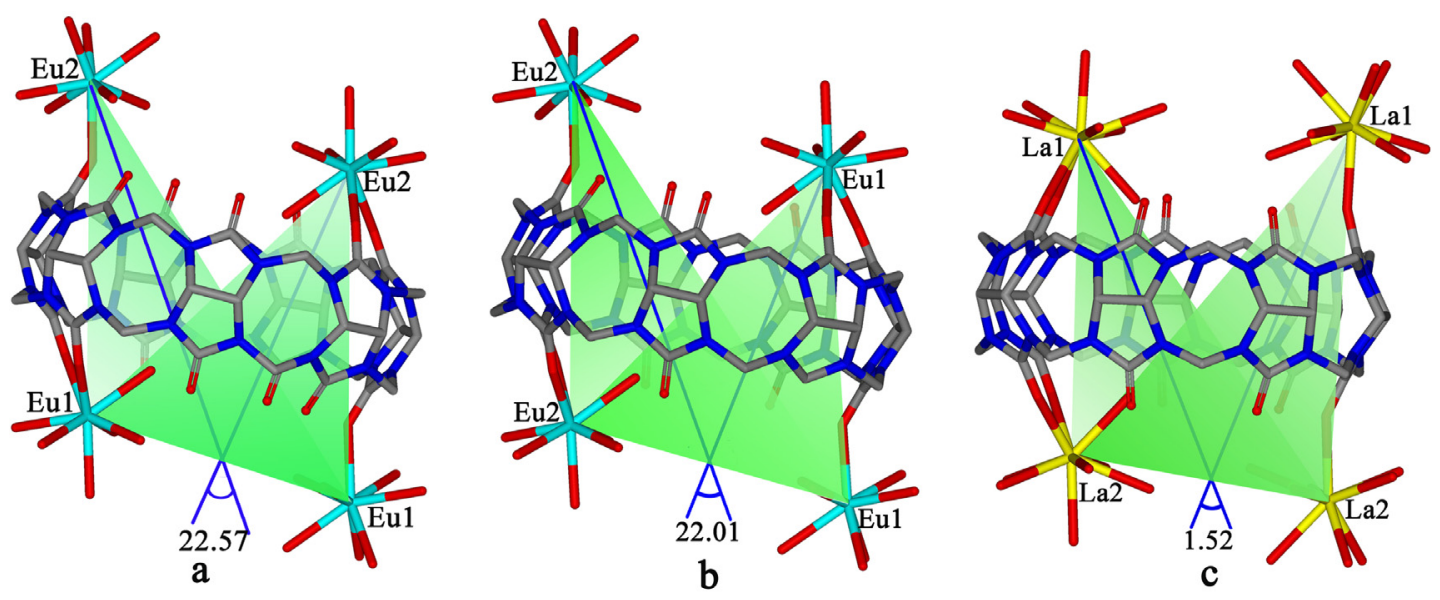

\section{Conclusions}

We have reported a series of coordination polymers prepared from $\mathrm{Ln}^{3+}$ cations and Q[7] molecules, in the presence of $\left[\mathrm{CuCl}_{4}\right]^{2-}$ or $\left[\mathrm{CoCl}_{4}\right]^{2-}$ anions as structure inducers. X-ray diffraction analysis has revealed that the compounds obtained can be divided into three isomorphous groups, namely the $\mathrm{Ln}^{3+}-\mathrm{Q}[7]-\left[\mathrm{CuCl}_{4}\right]^{2-}$ or $\left[\mathrm{CoCl}_{4}\right]^{2-}$ systems with light lanthanides in the first group, with systems with heavier lanthanides in the second or third groups. However, the crystal structures of these compounds show no significant differences. The $\left[\mathrm{CuCl}_{4}\right]^{2-}$ or $\left[\mathrm{CoCl}_{4}\right]^{2-}$ anions are present in a typical "honeycomb effect" and form honeycomb-like arrangements with hexagonal cells. The $\mathrm{Ln}^{3+}$ cations coordinate to the portal carbonyl oxygens of the Q[7] molecules to form tubular coordination polymers which occupy these hexagonal cells. Further detailed investigations are ongoing in our laboratories, with the aim of developing a useful practical synthetic technique. 


\section{Acknowledgments}

This work was supported by the National Natural Science Foundation of China (No. 20961002; 21101037); the Natural Science Foundation of the Department of Education of Guizhou Province, the Science and Technology Fund of Guizhou Province, the International Collaborative Project Fund of Guizhou Province, and the "Chun-Hui" Funds of the Chinese Ministry of Educationare also gratefully acknowledged.

\section{References}

1. Batten, S.R.; Champness, N.R.; Chen, X.M.; Javier, G.M.; Kitagawa, S.; Ohrstrom, L.; O'Keeffe, M.; Suh, M.P.; Reedijk, J. Coordination polymers, metal-organic frameworks and the need for terminology guidelines. CrystEngComm 2012, 14, 3001-3004.

2. Ye, B.H.; Tong, M.L.; Chen, X.M. Metal-organic molecular architectures with 2,2'-bipyridyl-like and carboxylate ligands. Coordin. Chem. Rev. 2005, 249, 545-565.

3. Côté, A.P.; Shimizu, G.K.H. Coordination solids via assembly of adaptable components: Systematic structural variation in alkaline earth organosulfonate networks. Chem. Eur. J. 2003, 9 , 5361-5370.

4. Ricci, G.; Sommazzi, A.; Masi, F.; Ricci, M.; Bogliaa, A.; Leonea, G. Well-defined transition metal complexes with phosphorus and nitrogen ligands for 1,3-dienes polymerization. Coord. Chem. Rev. 2010, 254, 661-676.

5. Carlucci, L.; Ciani, G.; Proserpio, D.M.; Rizzato, S. New polymeric networks from the self-assembly of silver(I) salts and the flexible ligand 1,3-bis(4-pyridyl)propane (bpp). A systematic investigation of the effects of the counterions and a survey of the coordination polymers based on bpp. CrystEngComm 2002, 4, 121-129.

6. Bureekaew, S.; Shimomura, S.; Kitagawa, S. Chemistry and application of flexible porous coordination polymers. Sci. Technol. Adv. Mater. 2008, 9, 014108-014120.

7. Fromm, K.M. Coordination polymer networks with s-block metal ions. Coord. Chem. Rev. 2008, 252, 856-885.

8. Yang, Y.; Jiang, G.Q.; Li, Y.Z.; Bai, J.F.; Pan, Y.; You, X.Z. Synthesis, structures andproperties of alkaline earth metal benzene-1,4-dioxylacetates with three-dimensional hybrid networks. Inorg. Chim. Acta 2006, 359, 3257-3263.

9. Freeman, W.A.; Mock, W.L.; Shih, N.Y. Cucurbituril. J. Am. Chem. Soc. 1981, 103, 7367-7368.

10. Day, A.I.; Arnold, A.P. Method for Synthesis Cucurbiturils. U.S. Patent 6,793,839 B1, 21 September 2004.

11. Kim, J.; Jung, I.S.; Kim, S.Y.; Lee, E.; Kang, J.K.; Sakamoto, S.; Yamaguchi, K.; Kim, K. New cucurbituril homo-logues: Syntheses, isolation,characterization, and X-ray crystal structures of cucurbit $[n]$ uril ( $n=5,7$, and 8). J. Am. Chem. Soc. 2000, 122, 540-541.

12. Day, A.I.; Blanch, R.J.; Arnold, A.P.; Lorenzo, S.; Lewis, G.R.; Dance, I. A cucurbituril-based gyroscane: A new supramolecular form. Angew. Chem. Int. Ed. 2002, 41, 275-277.

13. Lagona, J.; Mukhopadhyay, P.; Chakrabarti, S.; Isaacs, L. The cucurbit $[n]$ uril family. Angew. Chem. Int. Ed. 2005, 44, 4844-4870. 
14. Masson, E.; Ling, X.X.; Joseph, R.; Kyeremeh-Mensah, L.; Lu, X.Y. Cucurbituril chemistry: A tale of supramolecular success. RSC Adv. 2012, 2, 1213-1247.

15. Samsonenko, D.G.; Lipkowski, J.; Gerasko, O.A.; Virovets, A.V.; Sokolov, M.N.; Fedin, V.P.; Platas, J.G.; Rita, H.M.; Mederos, A. Cucurbituril as a new macrocyclic ligand for complexation of lanthanide cations in aqueous solutions. Eur. J. Inorg. Chem. 2002, 9, 2380-2388.

16. Samsonenko, D.G.; Gerasko, O.A.; Lipkowski, J.; Virovets, A.V.; Fedin, V.P. Synthesis and crystal structure of the nanosized supramolecular SmIII complex with macrocyclic cavitand cucurbituril $\left\{\left[\mathrm{Sm}\left(\mathrm{H}_{2} \mathrm{O}\right)_{4}\right]_{2}\left(\mathrm{C}_{36} \mathrm{H}_{36} \mathrm{~N}_{24} \mathrm{O}_{12}\right)_{3}\right\} \mathrm{Br}_{6} \cdot 44 \mathrm{H}_{2} \mathrm{O}$. Russ Chem. Bull. 2002, 51, 1915-1918.

17. Samsonenko, D.G.; Sokolov, M.N.; Gerasko, O.A.; Virovets, A.V.; Lipkowski, J.; Fenske, D.; Fedin, V.P. Syntheses and crystal structures of SmIII and ThIV complexes with macrocyclic cavitand cucurbituril. Russ Chem. Bull. 2003, 52, 2132-2139.

18. Gerasko, O.A.; Sokolov, M.N.; Fedin, V.P. Mono- and polynuclear aqua complexes and cucurbit[6]uril: Versatile building blocks for supramolecular chemistry. Pure Appl. Chem. 2004, $76,1633-1646$.

19. Yan, K.; Huang, Z.X.; Liu, S.M.; Feng, L.; Wu, C.T. Synthesis and crystal structure of new supramolecular adducts of $\left[\mathrm{PtCl}_{6}\right]^{2-}$ with cucurbit[7]uril: $\left[\left(\mathrm{H}_{3} \mathrm{O}\right)_{2}\left(\mathrm{PtCl}_{6}\right)\right]_{3}\left(\mathrm{C}_{42} \mathrm{H}_{42} \mathrm{~N}_{28} \mathrm{O}_{14}\right)_{2} \cdot \mathrm{H}_{2} \mathrm{O}$. Wuhan Univ. J. Nat. Sci. 2004, 9, 99-101.

20. Mit'kina, T.V.; Gerasko, O.A.; Sokolov, M.N.; Naumov, D.Y.; Fedin, V.P. Syntheses and crystal structures of supramolecular compounds of tetranuclear $\mathrm{Zr}^{\mathrm{IV}}$ and $\mathrm{Hf}^{\mathrm{IV}}$ aqua hydroxo complexes with macrocyclic cavitand cucurbituril. Russ. Chem. Bull. 2004, 53, 80-85.

21. Samsonenko, D.G.; Gerasko, O.A.; Virovets, A.V.; Fedin, V.P. Synthesis and crystal structure of a supramolecular adduct of trinuclear molybdenum oxocluster with macrocyclic cavitand cucurbit[5] uril containing the included ionic associate $\mathrm{Na}^{+} \mathrm{ClNa}^{+}$. Russ. Chem. Bull. 2005, 54, $1557-1562$.

22. Tripolskaya, A.A.; Mainicheva, E.A.; Mit'kina, T.V.; Gerasko, O.A.; Naumov, D.Y.; Fedin, V.P. $\mathrm{Sc}(\mathrm{III}), \mathrm{Eu}(\mathrm{III})$, and $\mathrm{Gd}(\mathrm{III})$ complexes with macrocyclic cavitand cucurbit[6]uril: Synthesis and crystal structures. Russ. J. Coord. Chem. 2005, 31, 768-774.

23. Liu, J.X.; Long, L.S.; Huang, R.B.; Zheng, L.S. Molecular capsules based on cucurbit[5]uril encapsulating "naked” anion chlorine. Cryst. Growth Des. 2006, 6, 2611-2614.

24. Shao, Y.; Li, Y.Z.; Shi, J.P.; Lu, G.Y. [ $\mu$-Cucurbit[6]uril(2-)]bis[pentaaquacalcium(II)] bis[tetrachloridozincate(II)]. Acta Crystallogr. 2007, E63, m1480-m1481.

25. Kasuga, N.C.; Umeda, M.; Kidokoro, H.; Ueda, K.; Hattori, K.; Yamaguchi, K. Four novel solid-state supramolecular assemblies constructed from decavanadate salts and decamethylcucurbit[5]uril. Cryst. Growth Des. 2009, 9, 1494-1498.

26. Liu, J.X.; Dong, C.H.; Long, L.S.; Huang, R.B.; Zheng, L.S. From 1D zigzag chain to 1D tubular structure, weak field ligand-dependent assembly of cucurbit[6]uril-based tubular coordination polymer. Dalton Trans. 2009, 36, 7344-7346.

27. Mainicheva, E.A.; Tripolskaya, A.A.; Gerasko, O.A.; Naumov, D.Y.; Fedin, V.P. Synthesis and crystal structures of PrIII and NdIII complexes with the macrocyclic cavitand cucurbit[6]uril. Russ. Chem. Bull. 2006, 55, 1566-1573. 
28. Mainicheva, E.A.; Gerasko, O.A.; Sheludyakova, L.A.; Naumov, D.Y.; Karsanova, I.I.; Amirov, R.R.; Fedin, V.P. Use of the macrocyclic ligand cucurbit[6]uril for isolation of tetranuclear lanthanide aquahydroxo-carboxylate complexes from aqueous solutions. Russ. Chem. Bull. 2006, 55, 1956-1965.

29. Tripol'skaya, A.A.; Mainicheva, E.A.; Gerasko, O.A.; Naumov, D.Y.; Fedin, V.P. Synthesis and crystal structure of a supramolecular adduct of the aqua nitrato complex of gadolinium $\left[\mathrm{Gd}\left(\mathrm{NO}_{3}\right)\left(\mathrm{H}_{2} \mathrm{O}\right)_{7}\right]^{2+}$ with macrocyclic cavitand cucurbit[6]uril. J. Struct. Chem. 2007, 48, 547-551.

30. Gerasko, O.A.; Mainicheva, E.A.; Naumova, M.I.; Yurjeva, O.P.; Alberola, A.; Vicent, C.; Liusar, R.; Fedin, V.P. Tetranuclear lanthanide aqua hydroxo complexes with macrocyclic ligand cucurbit[6]uril. Eur. J. Inorg. Chem. 2008, 416-424.

31. Thuéry, P. Uranylion complexes with cucurbit $[n]$ urils $(n=6,7$, and 8): A new family of uranyl-organic frameworks. Cryst. Growth Des. 2008, 8, 4132-4143.

32. Gerasko, O.A.; Mainicheva, E.A.; Naumova, M.I.; Neumaier, M.; Kappes, M.M.; Lebedkin, S.; Fenske, D.; Fedin, V.P. Sandwich-type tetranuclear lanthanide complexes with cucurbit[6]uril: From molecular compounds to coordination polymers. Inorg. Chem. 2008, 47, 8869-8880.

33. Thuéry, P. Lanthanide complexes with cucurbit $[n]$ urils $(n=5,6,7)$ and perrhenateligands: New examples of encapsulation of perrhenateanions. Inorg. Chem. 2009, 48, 4497-4513.

34. Thuéry, P. Uranyl-lanthanide heterometallic complexes with cucurbit[6]uril and perrhenate ligands. Inorg. Chem. 2009, 48, 825-827.

35. Thuéry, P. Uranyl ion complexes of cucurbit[7]uril with zero-, one- and two-dimensionality. CrystEngComm 2009, 11, 1150-1156.

36. Thuéry, P. Uranylion complexes with cucurbit[5]uril: From molecular capsules to uranyl-organic frameworks. Cryst. Growth Des. 2009, 9, 1208-1215.

37. Thuéry, P.; Masci, B. Uranylion complexation by cucurbiturils in the presence of perrhenic, phosphoric, or polycarboxylic acids. Novel mixed-ligand uranyl-organic frameworks. Cryst. Growth Des. 2010, 10, 716-722.

38. Thuéry, P. Second-sphere tethering of rare-earth ions to cucurbit[6]uril by iminodiacetic acid involving carboxylic group encapsulation. Inorg. Chem. 2010, 49, 9078-9085.

39. Thuéry, P. Uranylion complexation by aliphatic dicarboxylic acids in the presence of cucurbiturils as additional ligands or structure-directing agents. Cryst. Growth Des. 2011, 11, 2606-2620.

40. Thuéry, P. L-Cysteine as a chiral linker in lanthanide-cucurbit[6]uril one-dimensional assemblies. Inorg. Chem. 2011, 50, 10558-10560.

41. Hernandez, M.R.; Sokolov, M.N.; Sykes, A.G. Behavioral patterns of heterometallic cuboidal derivatives of $\left[\mathrm{M}_{3} \mathrm{Q}_{4}\left(\mathrm{H}_{2} \mathrm{O}\right)_{9}\right]^{4+}(\mathrm{M}=\mathrm{Mo}, \mathrm{W} ; \mathrm{Q}=\mathrm{S}, \mathrm{Se})$. Acc. Chem. Res. 2001, 34, 223-230.

42. Hernandez, M.R.; Sokolov, M.; Esparza, P.; Vicent, C.; Llusar, R. Aqueous solution chemistry of $\left[\mathrm{Mo}_{3} \mathrm{CuSe}_{4}\right]^{n+}(n=4,5)$ and $\left[\mathrm{W}_{3} \mathrm{CuQ}_{4}\right]^{5+}(\mathrm{Q}=\mathrm{S}$, Se $)$ clusters. Dalton Trans. 2004, 6, 847-851.

43. Fedin, V.P. New lines of research in chemistry of chalcogenide complexes: From clusters to supramolecular compounds. J. Coord. Chem. 2004, 30, 151-152.

44. Molina, R.H.; Sokolov, M.N.; Clausen, M.; Clegg, W. Synthesis and structure of nickel-containing cuboidal clusters derived from $\left[\mathrm{W}_{3} \mathrm{Se}_{4}\left(\mathrm{H}_{2} \mathrm{O}\right)_{9}\right]^{4+}$. Site-differentiated substitution at the nickel site in the series $\left[\mathrm{W}_{3} \mathrm{NiQ}_{4}\left(\mathrm{H}_{2} \mathrm{O}\right)_{10}\right]^{4+}(\mathrm{Q}=\mathrm{S}, \mathrm{Se})$. Inorg. Chem. 2006, 45, 10567-10567. 
45. Chubarova, E.V.; Sokolov, M.N.; Samsonenko, D.G.; Vicent, C.; Fedin, V.P. Supramolecular compounds of chloroaqua complexes $\left[\mathrm{Mo}_{3} \mathrm{Q}_{4}\left(\mathrm{H}_{2} \mathrm{O}\right)_{9-x} \mathrm{Cl}_{x}\right]^{(4-x)^{+}}(\mathrm{Q}=\mathrm{S}, \mathrm{Se} ; x=2,3$, 5) with cucurbit[n]urils. J. Struct. Chem. 2006, 47, 939-945.

46. Molina, R.H.; Kalinina, I.; Sokolov, M.; Clausen, M.; Platas, J,G.; Vicent, C.; Llusar, R. Synthesis, structure and reactivity of cuboidal-type cluster aqua complexes with $\mathrm{W}_{3} \mathrm{PdS}_{4}{ }^{4+}$ core. Dalton Trans. 2007, 550-557.

47. Abramov, P.A.; Sokolov, M.N.; Virovets, A.V.; Peresypkina, E.V.; Fedin, V.P. Synthesis and crystal structure of cucurbit[6]uril adduct of hydrogen-bonded cluster complex $\left[\mathrm{Mo}_{3}\left(\mu_{3}-\mathrm{Se}\right)\left(\mu_{2}-\mathrm{O}\right)_{3}\left(\mathrm{H}_{2} \mathrm{O}\right)_{6} \mathrm{Cl}_{3}\right]^{+}$. J. Clust. Sci. 2007, 18, 597-605.

48. Hernandez-Molina, R.; Kalinina, I.V.; Sokolov, M.N.; Peris, G.; Llusar, R. Studies on iron-containing chalcogenide clusters with core $\mathrm{M}_{3} \mathrm{FeQ}_{4}(\mathrm{M}=\mathrm{Mo}, \mathrm{W} ; \mathrm{Q}=\mathrm{S}, \mathrm{Se})$. Synth. React. Inorg. M. 2007, 37, 765-770.

49. Algarra, A.G.; Sokolov, M.N.; Gonzalez-Platas, J.; Fernandez-Trujillo, M.J.; Basallote, M.G.; Hernandez-Molina, R. Synthesis, reactivity, and kinetics of substitution in $\mathrm{W}_{3} \mathrm{PdSe}_{4}$ cuboidal clusters. Are examination of the kinetics of substitution of the related $\mathrm{W}_{3} \mathrm{~S}_{4}$ cluster with thiocyanate. Inorg. Chem. 2009, 48, 3639-3649.

50. Gushchin, A.L.; Ooi, B.; Harris, P.; Vicent, C.; Sokolov, M.N. Synthesis and characterization of mixed chalcogen triangular complexes with new $\mathrm{Mo}_{3}\left(\mu_{3}-\mathrm{S}\right)\left(\mu_{2}-\mathrm{Se}_{2}\right)_{3}{ }^{4+}$ and $\mathrm{M}_{3}\left(\mu_{3}-\mathrm{S}\right)\left(\mu_{2}-\mathrm{Se}\right)_{3}{ }^{4+}$ ( $\mathrm{M}=\mathrm{Mo}, \mathrm{W})$ cluster cores. Inorg. Chem. 2009, 48, 3832-3839.

51. Heo, J.; Kim, S.Y.; Whang, D.; Kim, K. Shape-induced, hexagonal, open frameworks: Rubidium ion complexed cucurbituril. Angew. Chem. Int. Ed. 1999, 38, 641-643.

52. Heo, J.; Kim, J.; Whang, D.; Kim, K. Columnar one-dimensional coordination polymer formed with a metal ion and a host-guest complex as building blocks: potassium ion complexed cucurbituril. Inorg. Chim. Acta 2000, 297, 307-312.

53. Zhang, F.; Yajima, T.; Li, Y.Z.; Xu, G.Z.; Chen, H.L.; Liu, Q.T.; Yamauchi, O. Iodine-assisted assembly of helical coordination polymers of cucurbituril and asymmetric copper(ii) complexes. Angew. Chem. Int. Ed. 2005, 44, 3402-3407.

54. Chen, K.; Liang, L.L.; Zhang, Y.Q.; Zhu, Q.J.; Xue, S.F.; Tao, Z. Novel supramolecular assemblies based on coordination of samarium cation to cucurbit[5]uril. Inorg. Chem. 2011, 50, 7754-7760.

55. Chen, K.; Feng, X.; Liang, L.L.; Zhang, Y.Q.; Zhu, Q.J.; Xue, S.F.; Tao, Z. Coordination and supramolecular self-assemblies of alkali and alkaline earth metal ions to cucurbit[5]uril in the presence of nitrophenol. Cryst. Growth Des. 2011, 11, 5712-5722.

56. Chen, W.J.; Yu, D.H.; Xiao, X.; Zhang, Y.Q.; Zhu, Q.J.; Xue, S.F.; Tao, Z.; Wei, G. Difference of coordination between alkali- and alkaline-earth-metal ions to a symmetrical $\alpha, \alpha^{\prime}, \delta, \delta^{\prime}$-tetramethylcucurbit[6]uril. Inorg. Chem. 2011, 50, 6956-6964.

57. Feng, X.; Du, H.; Chen, K.; Xiao, X.; Luo, S.X.; Xue, S.F.; Zhang, Y.Q.; Zhu, Q.J.; Tao, Z.; Zhang, X.Y.; Wei, G. Design and synthesis of self-assembly supramolecular entities based on noncovalent interaction of cucurbit[5]uril, metal ions, and hydroxybenzene or its derivatives. Cryst. Growth Des. 2010, 10, 2901-2907. 
58. Chen, K.; Liang, L.L.; Cong, H.; Xiao, X.; Zhang, Y.Q.; Xue, S.F.; Zhu, Q.J.; Tao, Z. $p$-Hydroxybenzoic acid-induced formation of a novel framework based on direct coordination of caesium ions to cucurbit[8]uril. CrystEngComm 2012, 14, 3862-3864.

59. Chen, K.; Cong, H.; Xiao, X.; Zhang, Y.Q.; Xue, S.F.; Tao, Z.; Zhu, Q.J.; Wei, G. Hydroquinone-induced framework based on direct coordination of rubidium ions to cucurbit[7]uril. CrystEngComm 2011, 13, 5105-5110.

60. Feng, X.; Chen, K.; Zhang, Y.Q.; Xue, S.F.; Zhu, Q.J.; Tao, Z.; Day, A.I. Stable cucurbit[5]uril MOF structures as "beaded" rings built on a $p$-hydroxybenzoic acid template-A small molecule absorption material. CrystEngComm 2011, 13, 5049-5051.

61. Liang, L.L.; Ni, X.L.; Zhao, Y.; Chen, K.; Xiao, X.; Zhang, Y.Q.; Redshaw, C.; Zhu, Q.J.; Xue, S.F.; Tao, Z. Construction of cucurbit[7]uril-based tubular nanochannels incorporating associated $\left[\mathrm{CdCl}_{4}\right]^{2-}$ and lanthanide ions. Inorg. Chem. 2013, 52, 1909-1915.

62. Liang, L.L.; Zhao, Y.; Zhang, Y.Q.; Tao, Z.; Zhu, Q.J.; Xue, S.F.; Liu, J.X. Coordination nanotubes self-assembled from cucurbit[7] uril and lanthanide cations. CrystEngComm 2013, 15, 3943-3950.

63. Liang, L.L.; Chen, K.; Ji, N.N.; Cheng, X.J.; Zhao, Y.; Xiao, X.; Zhang, Y.Q.; Zhu, Q.J.; Xue, S.F.; Tao, Z. Tetrachloride transition-metal dianion-induced coordination and supramolecular self-assembly of strontium dications to cucurbit[8]uril. CrystEngComm 2013, 15, 2416-2421.

64. Sheldrick, G.M. A short history of SHELX. Acta Crystallogr. A 2008, 64, 112-122.

65. Sheldrick, G.M. SHELXL-97 Program for the Solution and Refinement of Crystal Structures; University of Göttingen: Göttingen, Germany, 1997.

66. CCDC CIF Depository Request Form. Available online: http://www.ccdc.cam.ac.uk/data_request/cif (accessed on 9 May 2013).

67. Fang, X.K.; Kogerler, P.; Isaacs, L.; Uchida, S.; Mizuno, N. Cucurbit[n]uril-Polyoxoanion Hybrids. J. Am. Chem. Soc. 2009, 131, 432-433.

(C) 2013 by the authors; licensee MDPI, Basel, Switzerland. This article is an open access article distributed under the terms and conditions of the Creative Commons Attribution license (http://creativecommons.org/licenses/by/3.0/). 